\title{
Recombinant VLP-Z of JC Polyomavirus: A Novel Vector for Targeting Gene Delivery
}

\author{
Yong-Ning Deng ${ }^{\mathrm{a}}$ Jun-Yan Zeng ${ }^{\mathrm{a}}$ Hua Su $^{\mathrm{b}}$ Qiu-Min $\mathrm{Qu}^{\mathrm{a}}$

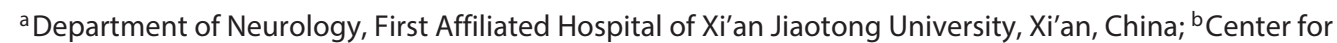 \\ Cerebrovascular Research, Department of Anesthesia and Perioperative Care, University of California, \\ San Francisco, Calif., USA
}

\section{Key Words}

$J C$ virus $\cdot$ Protein A - Target gene delivery $\cdot$ Virus-like particle

\begin{abstract}
Virus-like particle (VLP) of JC polyomavirus (JCPyV) is capable of packaging and delivering exogenous DNA into human cells and can be used for mediating therapeutic gene expression. However, many human cells express the JCPyV receptor. Thus, wild-type VLP can transduce a wide range of human cells nonspecifically. This study tested the feasibility of using a modified VLP with a IgG binding domain ( $Z$ domain) of protein $A$ in its capsid for targeted gene delivery. The $Z$ domain of protein A isolated from the membrane of Staphylococcus aureus was inserted into the $\mathrm{NH}_{3}$-terminus of $\mathrm{VP}_{1}$, the major JCPyV capsular protein. The recombinant VLP-Z was produced using Escherichia coli. Electron-microscopic analysis showed that VLP-Z has a viral-like structure. A hemagglutination test showed that VLP-Z has hemagglutination activity. $\mathrm{VP}_{1}$ was detected in the nuclei of HeLa cells by immunostaining after VLP-Z inoculation, suggesting that VLP$Z$ is viable and can enter the cell nucleus. Inoculating HeLa

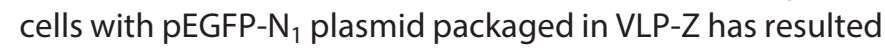
in enhanced green fluorescent protein expression in the cells. In addition, a binding assay showed that VLP-Z was
\end{abstract}

able to bind IgG through the interaction of the $Z$ domain in VLP-Z and IgG. These data suggest that VLP-Z could be armed with cell-specific antibody and be used to deliver therapeutic genes to target cells.

(c) 2016 S. Karger AG, Basel

\section{Introduction}

Recent clinical treatments of neurodegenerative diseases, such as Parkinson's disease, Alzheimer's disease, amyotrophic lateral sclerosis and spinal muscular atrophy, do not stop disease progression $[1,2]$. Gene therapy is a potential and powerful method to treat neurodegenerative diseases by introducing a normal gene to correct a mutant gene deficiency [2]. For gene therapy, vehicles for gene delivery are important. The recombinant JC virus-like particle (VLP) is a viral gene delivery vector. It can be easily generated in large quantities and at low cost. Exogenous genes can be packaged by the VLP and then delivered to cells susceptible to JC polyomavirus (JCPyV) for gene transduction [3].

$\mathrm{JCPyV}$ is a neurotropic virus that belongs to the Polyomaviridae. Simian virus (SV40), murine polyomavirus and $\mathrm{BK}$ virus all belong to this family. JCPyV is a nonen-

\section{KARGER 125}

(c) 2016 S. Karger AG, Basel

0300-5526/16/0586-0363\$39.50/0

E-Mail karger@karger.com

www.karger.com/int 
veloped, icosahedral DNA virus, has a genome made up of 5,130 bp and a circular double-stranded DNA that has three functional regions: an early coding region, a late coding region and a noncoding regulatory region [4]. The genes in the late coding region encode the structural capsid proteins, namely $\mathrm{VP}_{1}, \mathrm{VP}_{2}$ and $\mathrm{VP}_{3}$, as well as an agnoprotein. The recombinant JCPyV major capsid protein, $\mathrm{VP}_{1}$, can form VLP that has the typical morphology of empty JCPyV capsid. As native JCPyV, VLP is able to enter cells and be transported into the nucleus [5-7]. It has been shown that Escherichia coli-expressed $\mathrm{VP}_{1}$ is able to self-assemble into a capsid-like particle and deliver exogenous DNA into human kidney cells [8]. In vivo, VLP has been used to increase efficiency of gene transfer [9].

The JCPyV receptor is expressed in a wide range of cells of many species, as well as humans [9]. Thus, the transduction mediated by wild-type (wt) VLP is not cell specific [7]. As we know, cell-specific gene delivery is necessary for effective gene therapy. Combining $\mathrm{VP}_{1}$ with a different motif could change the character of JCPyV [10]. So we hypothesized that combining $\mathrm{VP}_{1}$ with another domain might improve the targeting ability of JCPyV. This study tested the use of the IgG binding domain ( $\mathrm{Z}$ domain) of protein A for therapeutic gene delivery to target cells. The $\mathrm{Z}$ domain isolated from Staphylococcus aureus membrane $[11,12]$ was inserted into $\mathrm{VP}_{1}$ at the $\mathrm{NH}_{3}$ terminus to generate a VLP-Z recombinant virus. The $\mathrm{Z}$ domain of protein A can bind Fc fragment of IgG antibody. Thus, VLP-Z particles armed with specific antibody can be used to deliver therapeutic genes to target cells.

This study demonstrated that E. coli-produced VLP-Z can transduce cultured cells, as well as package exogenous DNA, and mediate foreign gene expression in nuclei of transduced cells, as well as bind IgG.

\section{Materials and Methods}

\section{Cell Culture}

HeLa cells (human cervical carcinoma cells, JCRB 9004) were obtained from the Health Science Research Resources Bank (Osaka, Japan). The cells were cultured in Dulbecco's minimum essential medium (DMEM) supplemented with 10\% heat-inactivated fetal bovine serum, $2 \mathrm{~mm}$ glutamine, penicillin and streptomycin (Sigma-Aldrich, Shanghai, China) in a $37^{\circ} \mathrm{C}$ incubator with $5 \%$ $\mathrm{CO}_{2}$.

\section{Plasmid Construction}

The $\mathrm{wtVP}_{1}$ gene of JCPyV was isolated from pBR-Mad ${ }_{1}$ and subcloned into a prokaryotic expression vector, pET-15b (Nova- gen, Madison, Wis., USA). For the $\mathrm{VP}_{1}-\mathrm{Z}$ construction, $\mathrm{VP}_{1}$ and $\mathrm{Z}$-domain coding sequences were amplified by PCR using plasmid pET-15b and pE-ZZ18 (Amersham Pharmacia Biotech, Uppsala, Sweden) as template. The primer sequences of $\mathrm{VP}_{1}$ were 5-GCTCAGGCGCCGAAAATGGCCCCAACAAAAAG-3 (forward) and 5-GACAGGATCCTTACAGCATTTTTGTCTGCAAC-3 (reverse). The primer sequences of $Z$ domain were 5-CTGCGCAACACGATGCCATGGTAGACAACAAA-3 (forward) and 5-CTTTTTGTTGGGGCCATTTTCGGCGCCT-3 (reverse). The amplified $\mathrm{VP}_{1}$ and $\mathrm{Z}$ domain coding sequences were linked through recombinant $\mathrm{PCR}$ to generate $\mathrm{VP}_{1}-\mathrm{Z}$ fragment. The $\mathrm{VP}_{1}-\mathrm{Z}$ fragment was inserted into $\mathrm{pET}-15 \mathrm{~b}$ plasmid between BamHI and NcoI restriction enzyme sites (MBI Fermentas, Ottawa, Ont., Canada). The $\mathrm{VP}_{1}-\mathrm{Z}$ sequence was confirmed by sequencing.

\section{Preparation of VLP-Z Particles}

VLP-Z particles were prepared as previously described [13], with a few modifications. The $\mathrm{VP}_{1}$-Z-expressing plasmid was used to transform competent E. coli BL21(DE3)/pLys cells (Stratagene, La Jolla, Calif., USA). Protein expression was induced by incubating the transformed bacteria with $1 \mathrm{mM}$ isopropyl-D-thiogalactopyranoside at $30^{\circ} \mathrm{C}$ for $4 \mathrm{~h}$. After centrifugation for $10 \mathrm{~min}$ at $4,000 \mathrm{~g}$, the bacteria were collected and resuspended in $20 \mathrm{ml}$ of reassociation buffer [20 mM Tris- $\mathrm{HCl}(\mathrm{pH} 7.5), 150 \mathrm{mM} \mathrm{NaCl}$ and $1 \mathrm{mM} \mathrm{CaCl}_{2}$ ] containing lysozyme $(1 \mathrm{mg} / \mathrm{ml})$ and incubated on ice for $30 \mathrm{~min}$. After addition of sodium deoxycholate to a final concentration of $2 \mathrm{mg} / \mathrm{ml}$, the cells were incubated for an additional $10 \mathrm{~min}$ on ice and then lysed by five cycles of sonication (15-second bursts). Genomic DNA in the cell lysate was digested with DNase I (Amersham Pharmacia Biotech, Uppsala, Sweden). The lysate was then centrifuged through a layer of $20 \%(\mathrm{w} / \mathrm{v})$ sucrose at $100,000 \mathrm{~g}$ for $2 \mathrm{~h}$ at $4^{\circ} \mathrm{C}$. The pellet was resuspended in $1 \mathrm{ml}$ of $2 \mathrm{mg} / \mathrm{ml} \mathrm{CsCl}$ and centrifuged at $100,000 \mathrm{~g}$ for $16 \mathrm{~h}$ at $16^{\circ} \mathrm{C}$. Twelve fractions, $0.5 \mathrm{ml}$ per fraction, were collected and were subjected to a hemagglutination test. Fractions with activity $>1 \times 10^{6}$ were pooled and dialyzed for $24 \mathrm{~h}$ at $4^{\circ} \mathrm{C}$ with two changes of reassociation buffer $(1,000 \mathrm{ml})$.

\section{Hemagglutination Assay}

Production of VLP-Z particles was evaluated by hemagglutination of human erythrocytes and expressed as total yield, as described by Suzuki et al. [7]. A serial dilution of virus was prepared across the rows in U-bottom 96-well plates using $50 \mu$ of PBS containing $0.2 \%$ bovine serum albumin. After addition of $50 \mu \mathrm{l}$ of a $0.5 \%$ erythrocyte suspension to each well, the plates were incubated at $37^{\circ} \mathrm{C}$ for $1 \mathrm{~h}$. The end point was attained after incubation at $4^{\circ} \mathrm{C}$ for $3 \mathrm{~h}$. Bovine serum albumin was used as a negative control. The hemagglutination titer was defined as the reciprocal of the highest dilution of the virus suspension at which complete hemagglutination was observed.

\section{Electron-Microscopic Analysis of VLP-Z}

VLP-Z and wtVLPs were transferred to polyvinyl formal-coated grids and left for $5 \mathrm{~min}$. After removal of residual solution with filter paper, 10 drops of $2.5 \%$ phosphotungstic acid were placed onto each grid and allowed to air dry. VLP-Z were then observed with a model H-800 electron microscope (Hitachi, Tokyo, Japan). Electron microscopy revealed that both wtVLP and VLP-Z exhibited virion particle-like structures with a diameter of $40-50 \mathrm{~nm}$. 
Fig. 1. VLP-Z and wtVLP have a similar structure. a A representative picture of Coomassie brilliant blue-stained SDSPAGE gel. Arrows indicate wtVP $1(45 \mathrm{kDa})$ and $\mathrm{VP}_{1}-\mathrm{Z}(52 \mathrm{kDa})$ bands. b, c Representative pictures of electron micrographs of wtVLP and VLP-Z. Scale bars: $60 \mathrm{~nm}$.

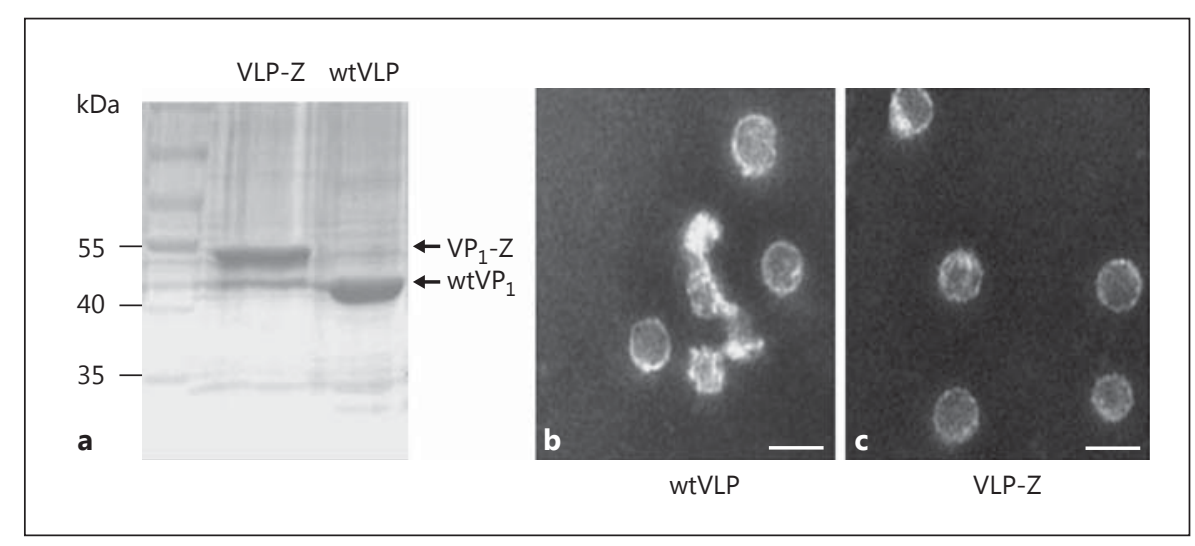

\section{Immunocytofluorescence Analysis}

Three hours after inoculation with 0.256 hemagglutination units of VLP-Z particles or wtVLP particles per cell in $2 \mathrm{ml}$ of DMEM supplemented with $10 \%$ fetal bovine serum, HeLa cells in $35-\mathrm{mm}$ glass bottom plates were washed three times with PBS and fixed with $4 \%$ paraformaldehyde for $15 \mathrm{~min}$ at room temperature and then $70 \%$ methanol for $5 \mathrm{~min}$ at $20^{\circ} \mathrm{C}$. The fixed cells were incubated with a mouse anti- $\mathrm{VP}_{1}$ antibody (1:500) [14] and then with Alexa 488-conjugated goat anti-mouse antibody (Molecular Probes, Eugene, Oreg., USA). The cells were examined and scanned using a laser-scanning confocal microscope (Olympus, Tokyo, Japan).

\section{Packaging Exogenous DNA into VLP-Z}

The method described by Goldmann et al. [15] and Forstová et al. [16] was used. Briefly, VLP-Z (0.5 mg) was incubated in $1 \mathrm{ml}$ of dissociation buffer [10 mM Tris- $\mathrm{HCl}(\mathrm{pH} 7.5), 150 \mathrm{mM} \mathrm{NaCl}, 10$ mM EGTA and $5 \mathrm{mM}$ dithiothreitol (DTT)] for $1 \mathrm{~h}$ at room temperature. pEGFP-N $\mathrm{N}_{1}$ plasmid $(3 \mu \mathrm{g})$, a plasmid expressing enhanced green fluorescent protein (GFP), was added to dissociated VLP-Z. The resulting mixture was dialyzed overnight at $4^{\circ} \mathrm{C}$ in $1,000 \mathrm{ml}$ of reassociation buffer. The membrane of the dialyzed bag had an exclusion size of $14 \mathrm{kDa}$. After addition of $6 \mathrm{mM} \mathrm{MgCl}_{2}$ and 10 units of DNase1, the mixture was incubated at $37^{\circ} \mathrm{C}$ for $1 \mathrm{~h}$. The VLP-Z containing pEGFP-N ${ }_{1}$ plasmid (VLP-Z-GFP) was isolated by centrifugation at $100,000 \mathrm{~g}$ for $1 \mathrm{~h}$ at $4^{\circ} \mathrm{C}$. The VLP-Z particles were resuspended in $200 \mu \mathrm{l}$ of PBS.

\section{In vitro Nuclear Transport Assay and PCR}

To examine whether VLP-Z can deliver DNA to the nucleus, HeLa cells were seeded onto $60-\mathrm{mm}$ plates and cultured for $24 \mathrm{~h}$ in DMEM. For inoculation, $0.8 \mathrm{mg} / \mathrm{ml}$ of VLP-Z-GFP or empty VLP-Z was added to $2 \mathrm{ml}$ of DMEM supplemented with $10 \%$ fetal bovine serum and incubated with the cells for $3 \mathrm{~h}$ at $37^{\circ} \mathrm{C}$. Total DNA was extracted from total cell lysates or from nuclear fractions prepared as described by Adam et al. [17] using a DNA extraction kit (Nucleobond AX; Macherey-Nagel, Easton, Pa., USA).

PCR was performed using GeneAmp PCR system 9700 (Applied Biosystems, Foster City, Calif., USA) in $50 \mu$ l of reaction mixture containing $1.0 \mu \mathrm{g}$ of isolated DNA, $0.2 \mathrm{mM}$ of each deoxynucleoside triphosphate and $0.1 \mathrm{mM}$ of each primer specific to pEGFP-N ${ }_{1}$. A three-step PCR was used: (1) denaturation: $95^{\circ} \mathrm{C}$ for $5 \mathrm{~min}$; (2) 35 amplification cycles: $95^{\circ} \mathrm{C}$ for $30 \mathrm{~s}, 60^{\circ} \mathrm{C}$ for $30 \mathrm{~s}$ and $72^{\circ} \mathrm{C}$ for $1 \mathrm{~min}$, and (3) final extension: $72^{\circ} \mathrm{C}$ for $10 \mathrm{~min}$.
The primer sequences were 5-GGTAAGACACGACTTATCGCCACT-3 (forward) and 5-GGAGTCAGGCAACTATGGATGAAC-3 (reverse). The PCR products were separated by electrophoresis on an agarose gel containing ethidium bromide and visualized with ultraviolet illumination.

\section{Binding Assay}

The binding assay was performed as described previously [18]. First, immunoblot analysis was used to test the binding effect. The proteins of wtVLP and VLP-Z without IgG were loaded onto $12 \%$ SDS-PAGE. After electrophoresis, proteins were transferred onto polyvinylidene fluoride (PVDF) membranes. Nonspecific protein binding was blocked with $5 \%$ nonfat dried milk in PBS for $2 \mathrm{~h}$. The membranes were incubated with a horseradish peroxidase (HRP)conjugated mouse monoclonal antibody to IgG (1:1,000) overnight at $4^{\circ} \mathrm{C}$. After washing with PBST [phosphate-buffered saline (PBS) with $0.05 \%$ Tween-20], the membranes were incubated with secondary antibodies conjugated with HRP at room temperature for $1 \mathrm{~h}$. The signal was detected using an enhanced chemiluminescence detection kit (Millipore, Billerica, Mass., USA). Second, 16 $\mu \mathrm{g} w \mathrm{w}$ VLP or VLP-Z were suspended in $20 \mu \mathrm{l}$ of PBS, mixed with $5 \mu \mathrm{l}$ of $\operatorname{IgG}(2 \mu \mathrm{g})$, incubated at room temperature for $2 \mathrm{~h}$ and then centrifuged at $100,000 \mathrm{~g}$ for $1 \mathrm{~h}$ at $4^{\circ} \mathrm{C}$. After being washed three times with PBS to remove free IgG, the pellets were resuspended in $20 \mu \mathrm{l}$ of PBS. The VLP-IgG complex was subjected to electrophoresis in $12 \%$ SDS-PAGE gel and then stained with Coomassie brilliant blue.

\section{Results}

\section{The VLP-Z Structure Is Similar to That of wtVLP}

Electron microscopy revealed that both wtVLP and VLP-Z exhibited a viral particle-like structure with a diameter of $40-50 \mathrm{~nm}$ (fig. 1b, c). The purified VLP-Z also has hemagglutination activity and the hemagglutination titer of VLP-Z particles is $1 / 128$. The purified VLP-Z yielded a prominent band of $52 \mathrm{kDa}$ on SDS-PAGE. The electrophoretic mobility of $\mathrm{VP}_{1}$-Z was slightly larger than that of $\mathrm{wVP}_{1}$ (45 kDa; fig. 1a). 
VLP-Z Can Package Exogenous DNA

To demonstrate whether VLP-Z truly packages exogenous DNA, the VLP-Z-GFP and a mixture of empty VLP-Z and pEGFP-N $\mathrm{N}_{1}$ were digested with DNase I. After digestion, the samples were assessed by PCR. Plasmid DNA was only detected in the sample of VLP-Z-GFP. No DNA was detected in the samples that have pEGFP- $N_{1}$ plasmid mixed with empty VLP-Z particles (fig. 2). These results demonstrate that VLP-Z is able to package DNA, and the DNA packaged in VLP-Z is resistant to DNase I digestion.

\section{VLP-Z Can Enter HeLa Cells and Their Nuclei}

After inoculating the HeLa cells with VLP-Z, the VP protein was detected in the nuclei by immunocytofluo-

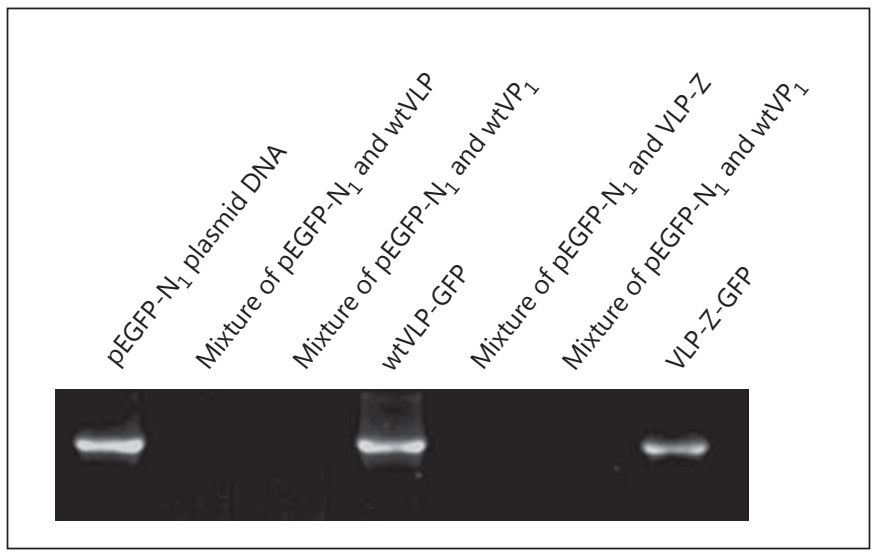

Fig. 2. VLP-Z packaged with DNA is resistant to DNase I. rescence staining. The location of $\mathrm{VP}_{1}$ in VLP-Z-inoculated cells was similar to that of cells inoculated with wtVLP (fig. 3).

\section{VLP-Z Delivers Packaged DNA into the Nuclei}

To investigate whether VLP-Z delivers packaged DNA into cell nuclei, total cell lysate or the nuclear fraction of HeLa cells inoculated with VLP-Z-GFP were analyzed by PCR. HeLa cells inoculated with wtVLP-GFP were used as a positive control. pEGFP- $\mathrm{N}_{1}$ plasmid DNA was detected in both total cell lysates and in the nuclear fraction of HeLa cells inoculated with VLP-Z-GFP and wtVLP-GFP. No DNA was detected in the cell lysates collected from cells incubated with a mixture of VLP-Z and $\mathrm{pEGFP}-\mathrm{N}_{1}$ plasmid (fig. 4). These data suggest that VLP-Z can deliver DNA into the nuclei of inoculated cells.

\section{VLP-Z Can Bind IgG}

In the VLP-Z binding assay, by immunoblot analysis, we found that VLP-Z interacted with IgG, but wtVLP did not (fig. 5a). Following incubation with IgG, VLP-Z and wtVLP were electrophoresed in SDS-PAGE gel. VLP-Z and wtVLP that had not been incubated with IgG were used as negative control. IgG $(30 \mathrm{kDa})$ was only present in the sample of VLP-Z incubated with IgG (fig. 5b). No IgG was detected in theother samples, including wtVLP incubated with IgG. $\mathrm{VP}_{1}-\mathrm{Z}(52 \mathrm{kDa})$ or wt $\mathrm{VP}_{1}$ were detected in all corresponding samples (fig. 5b). These results indicate that the $Z$ domain of protein A in VLP-Z is able to bind IgG.
Fig. 3. a VLP-Z can enter HeLa cells and their nuclei. $\mathrm{VP}_{1}$ protein was detected by immunofluorescence staining using a mouse anti- $\mathrm{VP}_{1}$ antibody. $\mathbf{b}$ wtVLP: location of $\mathrm{VP}_{1}$ similar to that in $\mathbf{a}$.
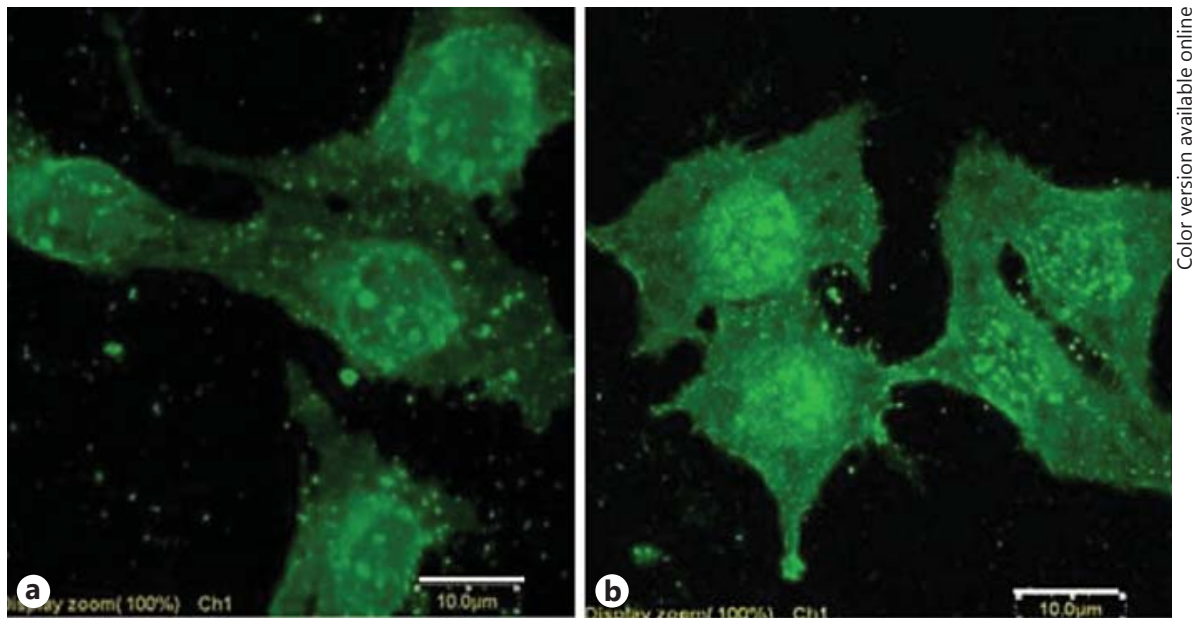


\section{Discussion}

In this study, the IgG binding domain of protein A was used to modify VLP VP 1 capsid protein. The resulting VLP-Z has a viral-like structure and physiological functions such as hemagglutination activity and intracytoplasmic trafficking, similar to those of wtVLP. VLP-Z is able to package exogenous DNA, transport it into the nucleus and mediate foreign gene expression in the inoculated cells. Importantly, VLP-Z can bind IgG, whereas wtVLP cannot. Thus, VLP-Z could be used to deliver therapeutic genes to target cells after being armed with cell-specific antibody.

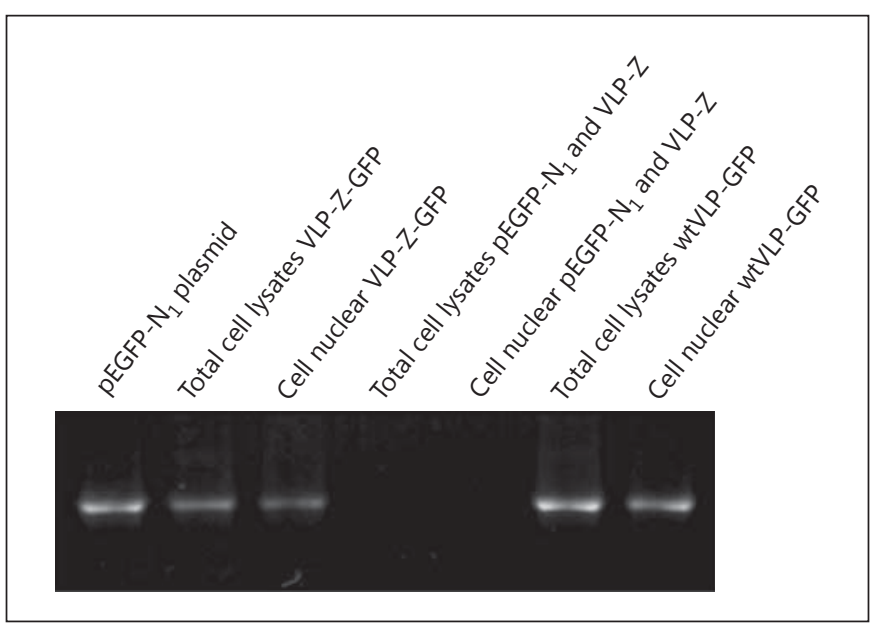

Fig. 4. VLP-Z packaged with pEGFP-N $\mathrm{N}_{1}$ plasmid was present in both total cell lysate and the nuclear extraction. Nuclear $=$ Nuclear fraction.
The major capsid proteins $\mathrm{VP}_{1}$ of JCPyV can assemble into VLP in the presence of calcium ions. The resulting VLP can be dissociated to $\mathrm{VP}_{1}$ in the presence of EGTA and DTT [19]. Through the dissociation and reassociation process, exogenous DNA can be packaged into VLP. The fact that the DNA packaged into VLP-Z was resistant to DNase I digestion, whereas the DNA mixed with VLP$\mathrm{Z}$ or with $\mathrm{VP}_{1}-\mathrm{Z}$ was not, indicates that exogenous DNA was located inside the VLP-Z particle.

VLP-Z packaged with $\mathrm{pEGFP}-\mathrm{N}_{1}$ was detected in the total cell lysate and nuclei of HeLa cells inoculated with VLP-Z-GFP, whereas the DNA was not detected in cells inoculated with a mixture of VLP-Z and pEGFP- $N_{1}$. These results suggest that VLP-Z is able to transport the exogenous DNA into cell nuclei. In addition, HeLa cells inoculated with VLP-Z-GFP expressed GFP. Cells inoculation with pEGFP- $\mathrm{N}_{1}$ plasmid alone did not express GFP. Thus, VLP-Z can mediate foreign gene expression and can be used to deliver therapeutic genes.

For target gene delivery, the $\mathrm{Z}$ domain of protein $\mathrm{A}$ was inserted into the $\mathrm{NH}_{3}$-terminus of $\mathrm{VP}_{1}$. The binding assay showed that VLP-Z interacted with IgG, but wtVLP did not. Thus, the $Z$ domain in VLP-Z enabled VLP-Z binding to IgG. It should be noted that in our experiment we just demonstrated that VLP-Z could bind to IgG. In the future, tags will be used to demonstrate the specificity of this binding assay.

In summary, the study demonstrated that insertion of a IgG binding domain of protein A into the $\mathrm{NH}_{2}$-terminus of JCPyV VP 1 did not alter the VLP structure and function significantly. The resulting VLP-Z exhibited physiological functions similar to those of wtVLP, and is
Fig. 5. Only VLP-Z can bind IgG. a Recombinant wtVLP or VLP-Z were subjected to SDS-PAGE and transferred to a PVDF membrane. The membrane was incubated with IgG and then detected with enhanced chemiluminescence reagents. The arrow indicates signals corresponding to $\mathrm{VP}_{1}-\mathrm{Z}$. b Recombinant wtVLP- or VLP-Z complexed with IgG were subjected to SDSPAGE and then stained with Coomassie brilliant blue.

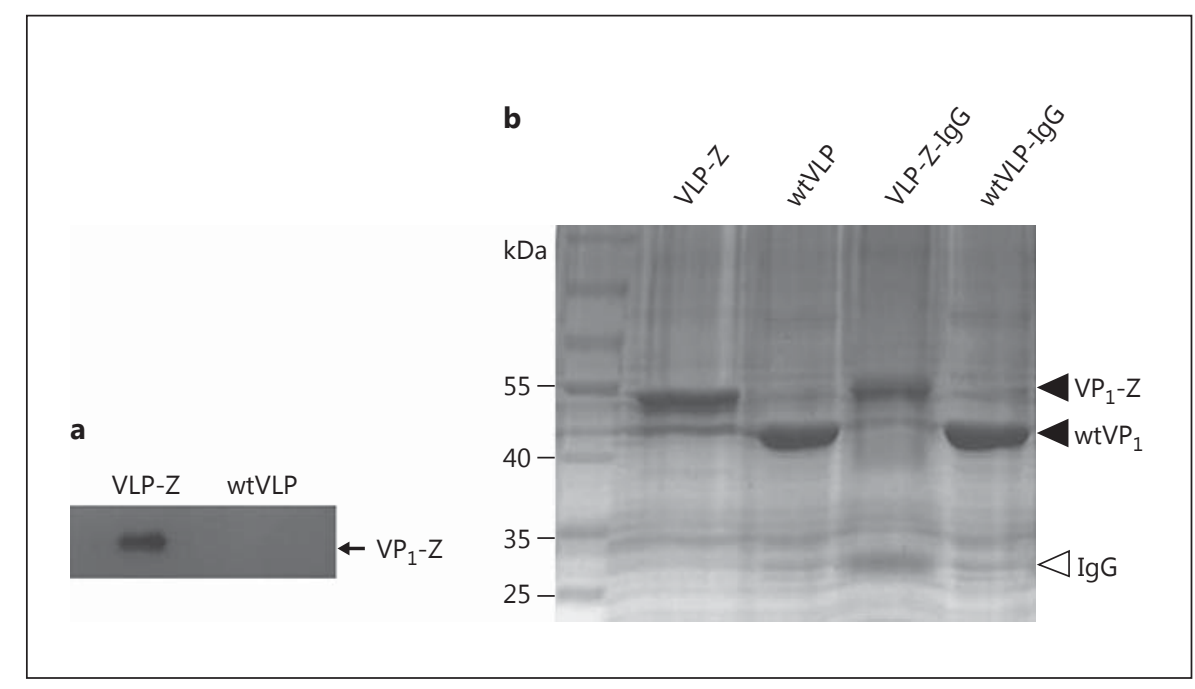

VLP-Z Recombinant Virus for Gene Delivery
Intervirology 2015;58:363-368 DOI: $10.1159 / 000443832$ 
able to package, deliver and mediate exogenous gene expression in human cells. Importantly, VLP-Z is able to bind the IgG molecule, whereas wtVLP cannot. Therefore, VLP-Z can be used as a vector for targeted gene delivery after being armed with cell-specific antibody. The effectiveness and safety of VLP-Z in the delivery of therapeutic genes to target cells in vivo are worth to be elucidated in the future.

\section{Acknowledgments}

We would like to thank Prof. Hirofumi Sawa (Laboratory of Molecular and Cellular Pathology, Hokkaido University School of Medicine, Sapporo, Japan) for technical assistance and valuable suggestions.

Grant sponsor: National Nature Science Foundation of China (to Q.M.Q.; grant No. 30570630).

\section{Disclosure Statement}

There is no conflict of interest.

\section{References}

1 O'Connor DM, Boulis NM: Gene therapy for neurodegenerative diseases. Trends Mol Med 2015;21:504-512.

2 Maguire CA, Ramirez SH, Merkel SF, SenaEsteves M, Breakefield XO: Gene therapy for the nervous system: challenges and new strategies. Neurotherapeutics 2014;11:817-839.

3 Chang CF, Wang M, Ou WC, Chen PL, Shen $\mathrm{CH}$, Lin PY, Fang CY, Chang D: Human JC virus-like particles as a gene delivery vector. Expert Opin Biol Ther 2011;11:1169-1175.

4 Frisque RJ, Bream GL, Cannella MT: Human polyomavirus JC virus genome. J Virol 1984; 51:458-469.

5 Chang D, Fung CY, Ou WC, Chao PC, Li SY, Wang M, Huang YL, Tzeng TY, Tsai RT: Selfassembly of the JC virus major capsid protein, VP1, expressed in insect cells. J Gen Virol 1997;78:1435-1439.

6 Goldmann C, Petry H, Frye S, Ast O, Ebitsch S, Jentsch KD, Kaup FJ, Weber F, Trebst C, Nisslein T, Hunsmann G, Weber T, Luke W: Molecular cloning and expression of major structural protein VP1 of the human polyomavirus JC virus: formation of virus-like particles useful for immunological and therapeutic studies. J Virol 1999;73:4465-4469.

7 Suzuki S, Sawa H, Komagome R, Orba Y, Yamada M, Okada Y, Ishida Y, Nishihara $\mathrm{H}$, Tanaka S, Nagashima K: Broad distribution of the JC virus receptor contrasts with a marked cellular restriction of virus replication. Virology 2001;286:100-112.
8 Ou WC, Wang M, Fung CY, Tsai RT, Chao PC, Hseu TH, Chang D: The major capsid protein, VP1, of human JC virus expressed in Escherichia coli is able to self-assemble into a capsid-like particle and deliver exogenous DNA into human kidney cells. J Gen Virol 1999;80:39-46.

9 Chen LS, Wang M, Ou WC, Fung CY, Chen PL, Chang CF, Huang WS, Wang JY, Lin PY, Chang D: Efficient gene transfer using the human JC virus-like particle that inhibits human colon adenocarcinoma growth in a nude mouse model. Gene Ther 2010;17:1033-1041.

10 Neu U, Maginnis MS, Palma AS, Stroh LJ, Nelson CD, Feizi T, Atwood WJ, Stehle T: Structure-function analysis of the human JC polyomavirus establishes the LSTc pentasaccharide as a functional receptor motif. Cell Host Microbe 2010;8:309-319.

11 Foster TJ, McDevitt D: Surface-associated proteins of Staphylococcus aureus: their possible roles in virulence. FEMS Microbiol Lett 1994;118:199-205.

12 Korokhov N, Mikheeva G, Krendelshchikov A, Belousova N, Simonenko V, Krendelshchikova V, Pereboev A, Kotov A, Kotova O, Triozzi PL, Aldrich WA, Douglas JT, Lo KM, Banerjee PT, Gillies SD, Curiel DT, Krasnykh $\mathrm{V}$ : Targeting of adenovirus via genetic modification of the viral capsid combined with a protein bridge. J Virol 2003;77:12931-12940.
13 Qu QM, Sawa H, Suzuki T, Semba S, Henmi C, Okada Y, Tsuda M, Tanaka S, Atwood WJ, Nagashima K: Nuclear entry mechanism of the human polyomavirus JC virus-like particle - role of importins and the nuclear pore complex. J Biol Chem 2004;279:27735-27742.

14 Okada Y, Endo S, Takahashi H, Sawa H, Umemura T, Nagashima K: Distribution and function of JCV agnoprotein. J Neurovirol 2001;7:302-306.

15 Goldmann C, Stolte N, Nisslein T, Hunsmann G, Luke W, Petry H: Packaging of small molecules into VP1-virus-like particles of the human polyomavirus JC virus. J Virol Methods 2000;90:85-90.

16 Forstová J, Krauzewicz N, Sandig V, Elliott J, Palkova Z, Strauss M, Griffin BE: Polyoma virus pseudocapsids as efficient carriers of heterologous DNA into mammalian cells. Hum Gene Ther 1995;6:297-306.

17 Adam SA, Marr RS, Gerace L: Nuclear protein import in permeabilized mammalian cells requires soluble cytoplasmic factors. J Cell Biol 1990;111:807-816.

18 Komagome R, Sawa H, Suzuki T, Suzuki Y, Tanaka S, Atwood WJ, Nagashima K: Oligosaccharides as receptors for JC virus. J Virol 2002;76:12992-13000.

19 Chen PL, Wang M, Ou WC, Lii CK, Chen LS, Chang D: Disulfide bonds stabilize JC virus capsid-like structure by protecting calcium ions from chelation. FEBS Lett 2001;500:109113. 